\title{
From Online Buddha Halls to Robot-Monks
}

\section{New Developments in the Long-Term Interaction between Buddhism, Media, and Technology in Contemporary China}

\author{
Stefania Travagnin \\ Faculty of Theology and Religious Studies, Department of the Comparative \\ Study of Religion, University of Groningen, Groningen, the Netherlands \\ s.travagnin@rug.nl
}

\begin{abstract}
The interaction between religion and the new media has affected the perception that society has of religion, changed cardinal structures in the relationship between religious practice and religious authorities, and also transformed features and functions of the media. If we look at mainland China today, religious individuals and groups have their own WeChat and Weibo accounts, and internet websites; some believers operate solely in cyberspace and perform rituals online; and commercials often adopt religious symbols to brand nonreligious products. In other words, we find religious people or organizations that use (and even own) different media platforms as channels of communication; we also see that religious imageries are more and more put to use in the secular domain for nonreligious purposes.

This article will analyze how and why Buddhists have resorted to social and digital media and even robotics to preach the Dharma and attract potential new followers, but also to redefine their public image in the wider Chinese society. This study also will ask whether the state has directed or merely engaged with this new Dharma mediaenterprise, and in what way. In addressing these questions, one section of this article will explore the creation of the robot-monk Xian'er (at the Longquan Monastery, Beijing). Xian'er's creation will be considered in relation to similar androids, placed in dialogue with the current debate on the use of robotics in religion, and viewed from posthumanist perspectives.
\end{abstract}




\title{
Keywords
}

artificial intelligence - digital religion - Buddhism - China - Longquan Monastery media robot-monks - Xian'er

\section{从在线佛堂到机器僧: 佛教、媒体与科技在当代现代中国的 互动与发展}

\author{
史芬妮 \\ 格罗宁根大学, 神学与宗教学学院, 比较宗教学系
}

\section{摘要}

宗教与新媒体之间的互动影响了社会对宗教的认知, 而通过改变宗教实践 与宗教权威关系的基本结构, 也同样改变了媒体的特性和功能。在当代中 国, 宗教人士与宗教团体都在利用微信、微博和互联网网站等各种社交媒 体来进行宣传。一些信徒在网络空间内进行各种宗教仪式。一些商业广告 也经常使用宗教符号来标记非宗教商品。换句话说, 我们发现宗教人士正 在利用不同的媒体平台作为传播渠道; 但另一方面, 宗教的意象越来越多地 被用于世俗领域的非宗教目的。

这篇文章将分析佛教徒是如何利用新媒体, 甚至是机器人, 来宣传佛 法并吸引潜在的新信徒, 从而重新定义中国社会中佛教的公共形象。此 外, 本研究也矢注中央政府是如何参与到新媒体领域中佛教的发展等问 题。为了更好地回答这些问题, 本文的将以北京龙泉寺的机器僧人贤二为 例, 重点探讨机器僧人贤二与其它宗教机器人的区别, 以及在当今社会中 对宗教机器人的争论, 并探讨如何在后人文主义视角下看待这些争论。

\section{关键词}

人工智能, 数字宗教, 佛教, 机器僧, 中国, 龙泉寺

Author: Xian'er, who are your parents?

Xian'er: Robots do not have parents.

Author: Xian'er, what do you prefer to eat?

Xian'er: I prefer ice-cream.

Author: Xian'er, how does one reach Buddhahood? 
Xian'er: The first step in the practice is to find a pure and harmonious Sangha community; it's like for a child who wants to learn first of all he needs to find a school. ${ }^{1}$

Conversations with the robot-monk Xian'er (xian'er jiqi seng 贤二机器僧), officially resident at the Longquan Monastery (Longquan si 龙泉寺) in Beijing, can be held anytime, in either Chinese or English, in person or on WeChat. Xian'er can talk with you about Buddhist issues, but also discuss matters of daily life; of course, Xian'er expects to joke with you, too, pretty much like a human monk, or an average human being, would do. You can practice sitting meditation with Xian'er on WeChat and choose the length of the meditation session; the gentle sound of wooden fish will mark the time, and Xian'er will announce the end of the session with the words "Amitabha, time is up" (Amituofo, shijian daole 阿弥陀佛, 时间到了). On the Internet or WeChat, you can also easily access online Buddha halls (zaixian fotang 在线佛堂) for digital sutra-copy practice and for offering digital incense, which, obviously, will neither smell nor vanish into smoke. Basically, all the major aspects of Buddhist practice in China have acquired a digital (and even robotic) form today, and you may very well cultivate the path in your living room or anywhere in the world where an Internet connection is available.

These are just some of the most recent digital manifestations of Buddhism in China. In fact, a continuous and constructive interaction between Buddhism and the media and technology has permeated all Asia and is also present in the West. On the one hand, Buddhists have used the latest technological tools, from the adoption of printing 2 to the use of electronic rosaries and Internet blogs, to preach, pray, and strengthen their own community. On the other hand, the same Buddhists have interacted with the domain of technology and eventually influenced the development of various media platforms (McGuire 2016). If we look at cinema and film production, for instance, films about the Buddha began to be released in Asia in the early twentieth century; ${ }^{3}$ some Korean movies

1 Conversation with the robot-monk Xian'er on his WeChat account "Xian'er the Robot-Monk" (xian'er jiqi seng 贤二机器僧), on December 9 and 11, 2018. Chinese original: 贤二, 你爸 妈是谁? 机器人没有爸妈的。你喜欢吃什么? 喜欢冰淇淋。贤二, 怎么成 佛? 修行的第一步是找到一个纯净和谐的僧伽社区, 如同小孩子学知识要先 找学校一样哦。

2 It is worth remembering that while the Gutenberg Bible was printed in the mid-fifteenth century, the first Chinese Buddhist canon had been printed a few centuries earlier, at the end of the ninth century.

3 The silent Hindi movie Prem Sanyas, which was produced by Franz Osten (1875-1956) at the end of the nineteenth century, was based on the British poet Sir Edwin Arnold's The Light of 
intertwine the theme of the sacred with nationalistic and historical elements, which become the real protagonists. ${ }^{4}$ We may also include here hagiographical portraits of Buddhist figures in different formats, such as documentaries or TV series. ${ }^{5}$ In the last one hundred years, journals, radio programs, ${ }^{6}$ the Internet (especially websites and blogs), ${ }^{7}$ music, ${ }^{8}$ digital media, ${ }^{9}$ and video games ${ }^{10}$ have also offered the figure of the Buddha and the tradition of Buddhism new possibilities of representation and interpretation.

Clearly, the interplay between religion and the media has affected the perception that society has of religion, changed cardinal structures in the relationship between religious practice and religious authorities, and transformed features and functions of the media. If we look at religious groups in China,

Asia; another silent black-and-white Indian movie titled Buddhadev (Lord Buddha) was produced in 1926 by Dadasaheb Phalke (1870-1944); the documentary Gotama the Buddha was broadcast by the government of India in 1956 to commemorate Buddha's 2,50oth birthday; and the Japanese film Shaka was produced in 1961 by Kenji Misumi. For more on the topic, see Travagnin 2016c.

4 See, for instance, Im Kwon-taek's Mandala (1981) and Aje aje para aje (1989), and Kim Kiduk's Spring, Summer, Autumn, Winter, and Spring (2004). For more about Buddhism in Korean films, see Cho 2003 and James 2002.

5 For example, the monk Dutugemunu became the main character of a controversial cartoon in Sri Lanka (Bartholomeusz 2002:63), and the life and career of the Korean monk Wŏnhyo was the subject of television programs, too.

6 In South Korea, for instance, the Buddhist Broadcasting System (ввS) was founded in 1990, and the Buddhist Television Network started later in 1995 (Jinmyong Sunim 2006). A few decades earlier, footage of the self-immolation of the monk Thich Quang Duc during the Vietnam War was shown on television outside of Vietnam as part of a Buddhist appeal to end the conflict; within Vietnam, denouncements of the violence against Buddhism that Thich Quang Duc was protesting had already been aired during Buddhist programs on local radio.

7 Tibetan initiation rituals can be transmitted via the Internet now, from temples in India or elsewhere outside Tibet, so as to reach the Tibetan community in diaspora and build a "virtual Tibet" (Helland 2014).

8 An example is the well-known Nepalese nun and singer Ani Choying Drolma (b. 1971), from the Nagi Gompa nunnery (a few hours from Kathmandu, in Nepal), who performs Tibetan Buddhist chants outside Tibet and records them on DVDs for mass distribution.

9 See McGuire 2019 for an overview of the digital possibilities that Buddhism and Buddhists have explored in the twentieth and twenty-first century.

10 A few recent examples include the video games Fight of Gods (2017), made in Taiwan, which includes the Buddha among the fighting deities (Wilkinson 2017), and Mandagon (2017), created by the game designer Tom Kitchen, now resident in Cardiff, UK, which inserts the player in a mystical world inspired by the Tibetan Buddhist idea of bardo (Gandhi 2017). 
WeChat, Weibo groups, and Internet websites are common; some believers operate solely in cyberspace and perform rituals online; and commercials often adopt religious symbols to brand nonreligious products (Puppin 2016). In other words, on the one hand religious people or organizations use (and even own) different media platforms as main channels of communication, and also as a way to become protagonists in nonreligious domains; on the other hand, religious imageries are adopted more and more frequently in the secular domain for nonreligious purposes.

This article will analyze how and why Buddhists in twenty-first century China have adopted social and digital media and even robotics not only to preach the Dharma and attract new followers, but also to redefine their public image in the wider Chinese society. Furthermore, this study will consider how the presence of religion in the media (especially on the Internet) was impacted by new regulations that were issued at the end of 2017, came into effect at the beginning of 2018, and were amended later toward the end of the same year. It highlights how, by establishing clear frameworks and margins of operation for Buddhism online, these regulations have affected the Buddhist cybersphere. Finally, this study will address a very recent development, the robot-monk Xian'er (at the Longquan Monastery, Beijing). Xian'er will be analyzed in relation to similar androids in China, like the calligraphy robot designed to resemble the philosopher Wang Yangming 王阳明 (1472-1529 AD) (in Guiyang); in parallel with the adoption of robots in other religious traditions; and within the wider field of artificial intelligence, robotics, and religion.

The first part of the article will start with a brief historical overview of various forms of interaction between Buddhism and the media in China, and it will also address analytical concepts and approaches that have been adopted to research this subject. The second part of the article will investigate in detail the question of artificial intelligence and robotics via the case study of Xian'er and advance new approaches and analytical categories that could enhance this field of study.

1

Chinese Buddhism, Media, and Technology: before and during the Time of Xian'er

1.1

The Long-Term Interaction between Buddhism, Media, and

Technology: Examples from China and Taiwan

In China, from the late Qing and early Republican period until now, Buddhists have used print media, music, radio and TV broadcasting (Pacey 2016; Tarocco 
2007; Travagnin 2016b), the Internet and social media (Pacey 2016; Huang 2016; McGuire 2016; Travagnin 2016b, 2019; Tarocco 2017, 2019), and finally automata. Hagiographical accounts of monks like Hongyi 弘 - (1880-1942 AD) or deities like the bodhisattva Guanyin 观音 have been subjects of films and DVDs. ${ }^{11}$

A similar scenario has unfolded in Taiwan as well. Most of the Buddhist printing and broadcasting efforts that started in mainland China in the early twentieth century had moved to Taiwan by the early 1950s, following the wave of sangha migration that occurred in those years, and in Taiwan they developed extensively. Even before the 1950s, during the Japanese occupation and independently of mainland China, the manifestation of religious ideas in the media had permeated Taiwan. In the colonial period, Buddhism was sometimes used in Japanese productions for political purposes as well, as in the Japanese film The Eyes of the Buddha (Dafo de tongkong 大佛的瞳孔, 1922), the first Taiwanese film directed by Tanaka King (Travagnin 2016b:58), which featured clear Japanese propaganda at the expense of Chinese values.

In Taiwan, from the late 1980 s, we notice the beginning of multifaceted Buddhist media enterprises. Buddhist organizations like Foguangshan and Tzu Chi opened their own media companies, which included publishing houses and TV and radio stations (Travagnin 2016b). And the lives of monks like Yinshun 印順 (1906-2005), Xingyun 星云 (1927-), and Dongchu 东初 (1908-1977), just to mention a few examples, were featured in motion pictures (Chia 2015; Pacey 2016; Travagnin 2016c).

Cross-strait exchanges between mainland China and Taiwan have included waves of transmission from the former to the latter (as in the mid-twentieth century), and also vice versa. Since the end of the twentieth century, and more frequently following the beginning of the twenty-first century, Buddhist organizations like Foguangshan, Fagushan, and Tzu Chi have opened branches in China. It is safe to argue that the Buddhist mediascape in mainland China today partakes of the same overall development of media and technology as any sector of Chinese society; at the same time, however, its development may also be a direct effect of the presence of Taiwanese Buddhist organizations and the strong links between the sanghas of mainland China and Taiwan. Taiwanese Buddhist groups such as Foguangshan set up a model and became key actors in

11 See, for instance, the biographical film about Hongyi titled Yilun mingyue 一轮明月 (A Bright Moon, 2009), directed by Chen Jialin 陈家林 and Lu Qi 路奇. For other examples, see Travagnin 2016c. For Buddhism and film in China, see Gao 2013. 
the making of what may be defined as the "third revival" of Buddhism in China in the most recent decades. ${ }^{12}$

The past two years have brought new changes and a reassessment of the religious mediascape in mainland China. Since the end of 2017, the growth of religious media has been challenged by new regulations imposed by China's State Council and the State Administration of Religious Affairs; new guidelines about Buddhism specifically were promulgated in meetings of the Buddhist Association of China (BAC) in 2018. In September 2017, the China's State Council issued new rules on religious affairs, effective as of February 2018; some included the call to oversee online religious activities. Two months later, specifically concerning Buddhism, the council declared that sites offering online worship of buddhas and bodhisattvas or any kind of memorial ceremony should not request any payment. ${ }^{13}$ The Central Religious Work Conference in 2016 (April 22-23) had already discussed the challenges posed by the Internet and so-called cyberactivities. Similar arguments emerged again in early July 2018. These regulations, which are collected in a document signed by President Xi Jinping 习近平 himself and titled "The Need to Give Attention to the Issue of Online Religions" (要高度重视互联网宗教问题), have been listed on the websites of several temples among the rules by which those temples must abide. According to this document, first, the Internet per se is not perceived as a problem, but the use of the Internet to propagate messages that contradict or oppose the principles of the Party is. Second, online religious activities that do not correspond to practices existing offline are prohibited; hence, what the believer finds online must be an exact replica of religious sites and activities that are conducted offline. Islam and Christianity are explicitly and specifically targeted in the document. The State Administration of Religious Affairs issued an additional document on September 11, 2018, that bans, among other things, the online burning of incense and liturgies. ${ }^{14}$ The new regulations that have been active since February 2018 are designed to further control and monitor

12 Recent studies on the concept of “revival” (fuxing 复兴) and reflections on whether or not it is appropriate to use this term to label the status of Buddhism in modern China include Ji, Tian, and Wang 2016; Schicketanz 2017; Travagnin and Laliberté 2019. See also Douglas Gildow's arguments in his article in this issue.

13 See “Development Status and Problems of Online Religion in China” 网络宗教在中国 的发展状况和问题. http://www.cwzg.cn/politics/201802/40888.html (accessed November 4, 2018).

14 See the "Measures on the Administration of Internet Religious Information Services" 互 联网宗教信息服务管理办法 promoted by SARA, http://www.sara.gov.cn/gzfw/yjzjy tc20170904204758792805/583838.htm, accessed November 3, 2018. SARA was dissolved in 2018, and its operations have been taken over by the United Front Work Department of 
the presence of religions online and the use of media by religious groups. They have had an impact on Chinese Buddhism as well, intersecting with the question of the commercialization of Buddhism ("Several Opinions on Further Governing the Commercialization of Buddhism and Taoism” 矢于进一步治 理佛教道教商业化问题的若干意见), which was discussed in one of the most recent meetings of the BAC (August 15, 2018). ${ }^{15}$ Nonetheless, websites of several temples still include the possibility of performing offerings to buddhas and bodhisattvas, and so do their WeChat accounts. In sum, at least at the time of writing (June 2019), these regulations have not yet affected online Buddhist rituals and practices.

\subsection{Critical Concepts, Research Approaches, and Arguments}

The theme of religion and the Internet in China has been the subject of only a few and very recent studies. My recent edited volume Religion and Media in China (Travagnin 2016a) included some reflections on how to approach the study of Chinese Buddhism and the media. Writing generally, Samuel Lengen (2016) pointed out that applications of new media and communication technologies in religious practice have been understood in terms of oppression and resistance a bit too much. Writing more specifically about Buddhism, Scott Pacey (2016) studied the emergence of "celebrity monks" in both mainland China and Taiwan using Singhal and Rogers's concept of "edutainment."16 Some scholars have underlined that the adoption of media has not affected the core of (individual) Buddhist practice and the sense of communitas created through collective practice (Huang 2016; Tarocco 2017, 2019); they detect continuities between offline and online forms of Buddhist practice, as the new opportunities provided by various media platforms have not really changed but rather maintained and enhanced the relations between sangha and laity. However, others have emphasized shifts and transformations; for instance, the performance of online rituals questions cardinal tenets of traditional (offline) ritual performance (Travagnin 2019). Some studies also investigate whether, and eventually how, political forces participate or intervene in these new forms of Dharma manifestations, and have underlined how religious practice online

the Central Committee of the Communist Party of China (中共中央统一战线工作 部).

15 See "Resolution of the Third Meeting of the Ninth Council of the Buddhist Association of China” 中国佛教协会第九届理事会第三次会议决议, http://www.chinabuddhism .com.cn/e/action/ShowInfo.php?classid=506\&id=39349, (accessed on October 31, 2018).

16 According to Singhal and Rogers (1999:xii), "edutainment" is "the process of purposely designing and implementing a media message to both entertain and educate." 
has been labeled (and encouraged) officially and in public spaces as a sign of civilization (wenming 文明) (Travagnin 2019). ${ }^{17}$

The study of robots in Chinese Buddhism is still in its infancy; the discussion of Xian'er in the second half of this article will sketch research approaches and arguments, in dialogue with the development of artificial intelligence in China, the adoption of robotics in other religions outside China, and a Buddhist reading of the new phenomenon.

\subsection{How Chinese Buddhists Perceive the New Media Age}

From the beginning of the twenty-first century, and during my first fieldwork in China, major temples in various provinces gifted me CDs or DVDs featuring profiles of the temples or the abbots' Dharma talks, in addition to pamphlets and short books. More recently, several nuns and monks passed me their business cards, printed with not a mere blog URL but also a few QR codes: one for the history and activities of their temples, one for personal communication with them, and others for their charities or educational programs. Posters with QR codes also greet visitors at several temples.

Certainly, the most outspoken monk to discuss the use of the media has been the former president of the BAC, the monk Xuecheng 学诚 (1966-; president of the BAC from 2015 to 2018). Xuecheng expressed positive views on the use of media by Buddhists, arguing that media in religion is a necessary tool in the time in which we live today; this view reflected the adoption of media in other cultural sectors and in daily life in China and beyond. ${ }^{18}$ Similarly to Taixu in the beginning of the twentieth century, and Xingyun in the 196os, Xuecheng also found the Buddhist use of media to be consonant with the movement to create a "Buddhism for the Human Realm" (renjian fojiao 人间佛教) that emphasized the needs of people in this lifetime and not just the next (Huikong 2012:172). Xuecheng was the first Buddhist monk in China to found his own

17 For an extensive overview of the field of study, see Travagnin 2019. Recent scholarship on various aspects and functions of media and technology in China includes Hui 2016, Mengin 2004, and Pickard and Yang 2017.

18 Quoting Xuecheng: "Buddhists and Buddhism accept and welcome all advanced science, and we are paying attention to the development of technology" (Huikong 2016:254). And also: "This is an Internet age. The development of each industry depends on the Internet. Everything is connected to each other in the same way as the Internet links up different things completely. Isolation is equivalent to weakness. That's why all industries and organizations rely heavily on the Internet, which shows the strength of collective karma. Being connected as one is collective karma. We will be weak if what we Buddhists do only creates individual karma. If we are weak, we are unable to influence society extensively" (Huikong 2016:246). 
blog (in October 2006) and to use an Internet channel to promote (his) Buddhist teachings. As I explained in a previous publication (Travagnin 2019), Xuecheng also referred to the label "the fourth power" (disizhong quanli 第四 种权力 $)^{19}$ when defining the media and claimed that it was indeed very useful in the globalized world (Xuecheng 2012). ${ }^{20}$ Xuecheng regards the use of the media as a way to reach a larger audience. As he said on several occasions, including when the robot-monk was created, "Buddhism is from an ancient time, but Buddhist followers are part of today” (佛教是古来的, 但是佛教徒是 现在的). Xuecheng does see media as a medium. However, he does not seem to be either aware or concerned about the process of mediation, namely how the use of media can affect the message one transmits.

The monk Yinneng 印能 (1976-) also commented positively on the use of the media and the process of modernization that is ongoing within the Buddhist sphere. A native of Jilin who currently resides in Shenzhen, Yinneng has more than one million followers on Twitter for his performances, in China and abroad, and recordings of Buddhist chants and various liturgies. As he told me, his performances combine traditional sutra and prayer recitations with modern music so as to adjust to the times and better convey Buddhist messages to a contemporary audience. Yinneng uses Weibo and WeChat regularly to communicate his thoughts and present his new music; he is convinced that these updates and changes show that Buddhism can, in fact, "adapt to the time without compromising the Buddha's core principles (qili qiji契理契机).”21

At the same time, however, Xuecheng imposed very strict rules on who, among the monks and nuns of the monasteries he supervised, could use cell phones and access the online world. According to my interviews with monks from the Longquan Monastery and nuns from the Jile Nunnery (Jile si 极乐 寺), ${ }^{22}$ in the last two years of Xuecheng's abbotship only a small number of

19 Xuecheng here is referring to the traditional concept of powers or estates in Christian Europe from the Middle Ages up to the French Revolution. The first three powers (or estates) are the clergy, the aristocracy, and the masses. From the end of the eighteenth century, the media (at that time limited to the press) was defined as a fourth power or estate.

20 This article was posted on the Longquan Monastery website as well (http://www .longquanzs.org/lqs/hcfs/hcfs/46884.htm; accessed on July 10, 2019), and was suggested to me by monks and volunteers at Longquan as a good way to really understand Xuecheng's position on the use of media.

21 Personal communication, June 6, 2019.

22 Jile Temple, in Fujian, is a nunnery whose abbot was Xuecheng until late summer 2018. For more about Xuecheng's career as abbot, see Zhang 2017. 
clerics who held specific positions of responsibility were allowed to use cell phones. The rest of the sangha was not allowed to access these tools, since these could have distracted them from their daily cultivation.

Clerics from other monasteries also shared their concern regarding the negative impact that technology, in the form of social media and new media, might have on individual cultivation, especially in the case of young monks who, in their view, need direct master-disciple supervision instead. Again, the usefulness and the dangers of Buddhism and Buddhists' adoption of media are both underlined (see also Travagnin 2019). Other clerics confirmed that there is awareness that machines can alienate people and make them neglect contacts with others offline, but maintained that there is still a need to create machines that can help individuals to introspect, with the caveat that they still have to find a way to reconnect with people. Nuns share similar views, pointing out that in the use of social media and new media there is a thin line between creating a form (and sense) of community and alienating individuals in their offline social attitudes; for these nuns, what happens in a religious context simply reflects other situations of social behavior and interaction in daily life. ${ }^{23}$

The contrasting opinions expressed by monastics are also voiced by Buddhist laity whom I have interviewed in the past few years. They all admitted to the convenience (fangbian 方便) that technology and new media contributed to Buddhist practice, but also confessed that online activities do not offer them the same spiritual experience and sensations as offline activities.

Robotics are a very recent addition to the Buddhist mediascape in contemporary China and, as such, have not been addressed and studied yet in detail. Before going into research methods and conceptual approaches, I will give a brief overview of what Xian'er is, how it was planned and created at the Longquan Monastery in Beijing, and, consequently, how it is a specifically Longquan-branded creation.

\subsection{Xian'er's Biography: from Comics to Robotics}

The history of the character of Xian'er started with the foundation of the Animation Center (donghua zhongxin 动画中心) at the Longquan Monastery in

23 Interviews conducted in Chengdu, Beijing, Nanjing, and Tianjin in 2015, 2017, and 2019. Contacts via WeChat have been kept regularly since 2017. 
the end of 2011. ${ }^{24}$ Although the monastery started producing cartoons in November 2011, ${ }^{25}$ the character of Xian'er was not created until 2013, drawn by the monk Xianfan 贤帆.

The production started with a simple single-panel comic, which was followed by more sophisticated multipanel strips. The same year also saw the first work on stop-motion animations of Xian'er, including dough-figurine animation, which merged a traditional craft from China with new technologies. These were followed by $3 \mathrm{D}$ animations of various stories and, finally, by oneminute Flash clips titled Master Xuecheng's New Talks (Xuecheng xinyu 学诚新 语), which were based on the comic Dharma Talk at Jianxing Hall (Jianxing tangyu 见行堂语). So far, the Animation Center has produced more than one thousand cartoons about Xian'er. ${ }^{26}$ Between 2014 and 2015, comic books featuring Xian'er started to be published in book format, too (Xuecheng, Xianfu, and Xianshu 2014, 2015a, 2015b). The Animation Center participated in several cartoon festivals and was nominated for a few awards. ${ }^{27}$

While the monk Xianfan draws the figure of Xian'er, it is the monk Xianshu who writes the dialogue. The stories portrayed have been mostly related, more or less directly and explicitly, to the teachings of Xuecheng; in other words, Xian'er became an alternative channel for Xuecheng to deliver his sermons when he was the abbot of Longquan. Even today, after his downfall in summer 2018, Xuecheng's words are echoed in Xian'er's cartoons. ${ }^{28}$ In the preface to a comic book, Xuecheng underlined the importance of the "transmission" (chuanbo 传播) of the Dharma and his own teachings and on how helpful the monks Xianfan and Xianshu had been in translating his words into vignettes and comics, thus making those teachings more understandable and accessible to everyone. In fact, comics (manhua 漫画) have been a crucial channel of "transmission" at Longquan since 2011. Xuecheng argued that everyone likes

24 See Zhang (2015) for an overview of the use of communication technology in Longquan Monastery before the creation of the robot-monk Xian'er, and Xuecheng's media strategies.

25 Before the creation of Xian'er, the Animation Center created figurines of traditional characters in Chinese history and culture, not always Buddhism-related.

26 Some of the animations were broadcast on CCTV in 2017.

27 In 2013, the Animation Center was the only religious participant in the Beijing International Cartoon Exhibition; in 2014, it was nominated for the Golden Monkey King award at the Hangzhou Cartoon Festival and the Golden Dolphin award at the Xiamen Cartoon Festival.

28 In 2018, Xuecheng was forced to leave his position as head of the BAC and abbot of the Longquan Monastery following a scandal in which he was accused of corruption and sexual misconduct (Johnson 2018). 
comics, both in the East and in the West; moreover, comics are structured in such a way that their message can be easily translated into various languages, thus facilitating internationalization in the preaching of the Dharma. ${ }^{29}$ For these reasons Xuecheng promoted the translation of Dharma teachings into comics during his abbotship of the Longquan Monastery and authorized the production of a series of comic books where the figure of Xian'er interacted with fellow monks, its teacher, and lay believers. Xuecheng's Dharma teachings have been translated into comics even since his resignation in August 2018; these publications have included prefaces by Xuecheng.

The comics provide further evidence of the close connection between the development of Buddhist media in mainland China and the Buddhist mediascape in Taiwan in several ways. For instance, in the second preface of the comic book published in 2014, the founder of Foguangshan Xingyun wrote that reading manga can be a vehicle to access the Dharma (kan manhua ru famen 看漫画入法门). In fact, Foguangshan had published a Collection of Comics on Eminent Buddhist Monks (Fojiao gaoseng manhua quanji 佛教高僧漫画全 集) already in 2000. ${ }^{30}$ Another volume of Xian'er comics includes a preface by the famous Taiwanese manga author Cai Zhizhong 蔡志忠 on the topic of "manga Chan" (manhua chan 漫画禅).${ }^{31}$ Of course, the use of vignettes to promote Buddhist teachings is not an innovation of the twenty-first century; the monk Hongyi and the lay Buddhist Feng Zikai 丰子恺 (1898-1975) had already adopted that tool in the early and mid-twentieth century (Tarocco 2007).

The robot-monk Xian'er was the result of collaboration between Longquan Monastery and lay experts in technology and artificial intelligence. ${ }^{32}$ The firstgeneration robot was inaugurated in October $2015,{ }^{33}$ and one year later, in October 2016, the second-generation robot was added to the previous one; this second version was taller, had moving arms, and a greater variety of communication methods. A third robot, in the form of the first-generation robot, was introduced in June 2018. This Xian'er can debate with its interlocutor with higher sophistication; for instance, it not only answers others' queries but also

29 See the first preface to Xuecheng 学诚, Xianfu 贤帆, Xianshu 贤书 2014.

30 See the second preface to Xuecheng 学诚, Xianfu 贤帆, and Xianshu 贤书 2014.

31 See the preface to Xuecheng 学诚, Xianfu 贤帆, and Xianshu 贤书2015a.

32 Plans to create a robot started in early 2015; the first lay AI experts involved in this mission were the well-known Yu Zhichen 俞志晨, CEO of Turing Robot (Tuling jiqiren 图灵机器 人), and Song Yunfei 宋云飞, CEO of One Robot (Feiyue jiqiren 飞跃机器人).

33 Xian'er was created and activated on September 25, 2015, which is usually remembered as its birthday. However, its unveiling ceremony and effective inauguration is dated to October 1. 
questions those same queries; it does not always obey when someone tells it to do something but likes to express reservations and even raise objections. During my last visit, in early June 2019, Xian'er refused to dance or walk in a circle for us; it asked us why it had to do that and none of our answers were, in its view, satisfactory. In all the three generations, Xian'er robot's sense of touch is acute: it tells you quite frankly how annoying it is when you touch its ears, and if you do the same with its bottom, then it shouts that you should not grab a monk's bottom and runs away. On the other hand, the third-generation Xian'er is becoming more responsive and interactive than the iPhone's Siri.

WeChat has been popular in China since 2014, and Xian'er opened its own WeChat account on October $1,2015,{ }^{34}$ the day of its unveiling at the monastery. Under the WeChat ID “Xian'er the Robot-Monk” (Xian'er jiqiseng 贤二机 器僧), Xian'er interacts and communicates in various ways. Wall posts include comics and animations that feature the robot-monk, as well as audio recordings of Xian'er's recitation of passages from Xuecheng's teachings and canonical texts. ${ }^{35}$ WeChat users can also leave comments on these posts, a practice that was highly encouraged by the Animation Center itself as a means to study the reception of Xian'er and improve its communication skills. WeChat has also been used to inform the public of new developments in Xian'er's career, such as the creation of the first-generation robot (end of September 2015), its unveiling at the Longquan Monastery (October 1, 2015), ${ }^{36}$ and its participation in the Guangzhou Cartoon and Animation Festival (Guangzhou Dongmanjie 广州动漫节; October 3, 2015), ${ }^{37}$ where, as the poster displayed at the festival announced, human beings could connect (jieyuan 结缘) with the first Buddhist robot-monk in Chinese history. The Animation Center also used WeChat to post multipanel strips in which the cartoon-protagonist Xian'er

34 The first pages appeared on September 25, 2015, when the robot was activated. However, WeChat users could not add Xian'er as a friend until October 1.

35 See, for instance, the recitation on June 27, 2019, "Xian'er reads for you the 'Pure Practice chapter' of the Avatamsaka Sūtra - part three” 贤二为你读 《华严经 - 净行品》之 三, https://mp.weixin.qq.com/s/Bf $3 X_{1} W_{Z} m_{7} \mathrm{RU}_{5} \mathrm{cJtP} 24 \mathrm{ZA}$ (accessed on July 1, 2019).

36 See the news items posted on September 25, 2015: "Robot-Monk Xian'er: Exploring the deep integration between Buddhism and science” 贤二机器僧:探索佛教与科学深度 融合, https://mp.weixin.qq.com/s/h9vzFlC_344EljcRF5n5pg (accessed July 1, 2019); “Robot-Monk Xian'er Album: Today is My Birthday” 贤二机器僧影集：今天是我生 日, https://mp.weixin.qq.com/s/GrOıTog 4 EHeOoYpUUTIBtA (accessed July 1, 2019).

37 See the news item posted on October 5, 2015: “Robot-Monk Xian'er in Guangzhou” 贤二 机器僧在广州, https://mp.weixin.qq.com/s/436gjR5HODPgB_9X1uTa7w (accessed July 1, 2019). 
interacts with the robot-monk Xian'er. ${ }^{38}$ The cartoon Xian'er feels challenged by the homonymous robot's fame and popularity, and the two of them often disagree when it comes to good behavior and Buddhist conduct. Overall, the cartoon-protagonist Xian'er appears more clever but less advanced in its understanding of Buddhist principles and practice; the homonymous robotmonk comes out as more vulnerable and certainly less human, ${ }^{39}$ but, considering its attitude and speech, it seems to have reached a higher level of Dharma cultivation. WeChat lets the users interact directly with Xian'er via the series of “Xian'er's mini-programs" (Xian'er xiao chengxu 贤二小程序); through these, anyone can communicate with Xian'er as they would with any other WeChat user, ${ }^{40}$ asking questions about Buddhism but also sharing thoughts and concerns about everyday life. WeChat users can even meditate with Xian'er for a predefined amount of time, or, to make it happy, shower it with lotus petals!

Since July 2016, various souvenirs with Xian'er's likeness, from T-shirts to magnets, have been produced and sold at the monastery or at other locations in Beijing, and in Longquan branch temples outside of China. ${ }^{41}$ My last visit in June 2019 confirmed that this merchandising is still ongoing, which means that it has not been considered to be a violation of the BAC's August 2018 ruling against the commercialization of Buddhism.

38 See the multipanel strips “Robot-Monk Xian'er, please do help me” 贤二机器僧, 帮帮 我吧, October 13, 2015, https://mp.weixin.qq.com/s/a7oYBMrvWL9A6ea5Db-aXQ; "Robot-Monk Xian'er, clean the toilet for me” 贤二机器僧, 替我去刷马桶, October 4, 2015, https://mp.weixin.qq.com/s/8OMJLAOZZJoew-Qt2UqchQ; “Robot-Monk Xian'er: There is no such action in my program” 贤二机器僧 : 我的程序里没有这个动作 啊, September 30, 2015, https://mp.weixin.qq.com/s/75ytghyDmIfnHsyXzC7ocg; "Master, are you also chatting with the Robot-Monk?” 师父, 你也在和机器僧聊天吗? , October 12, 2015, https://mp.weixin.qq.com/s/Fkp1cgixcC2Ve3xM8w-e_w; "With the RobotMonk Xian'er, Xian'er became miserable” 有了贤二机器僧, 贤二惨了, October 10, 2015, https://mp.weixin.qq.com/s/vYYh5zRG7WFkufdDwNqoyA; "Who said to ask you, we ask the Robot-Monk” 谁说问你了, 我们问机器僧, October 8, 2015, https://mp .weixin.qq.com/s/EBv-gyIDpCvTBDW3-TtyBA; “Selection of Questions That Fans of Cute Xian'er Robot-Monk ask him” 可爱的贤二机器僧粉丝提问摘选, October 6, 2015, https://mp.weixin.qq.com/s/v5gplwE5wh2_WZ9oUmrb6A (all accessed July 1, 2019).

39 It can be turned off with a switch, for instance, and cannot express as many human emotions as the cartoon-protagonist Xian'er.

40 Since 2017, Xian'er can also communicate in English.

41 There are branches of Longquan in the Netherlands (Dabei si 大悲寺), Botswana (Bohua $s i$ 博华寺), Tanzania (Tanhua si 坛华寺), and the United States (Guanyin si 观音寺); there is a plan to consecrate and inaugurate other temples in Germany and Italy. 
Finally, in 2016 a lay practitioner and volunteer at Longquan opened a Xian'er-themed vegetarian restaurant, Xian'er Family (Xian'er jia 贤二家), not far from the monastery. Xian'er decorations appeared within the restaurant too, even on bags and packages. Between November and December 2018, the icon of a red bird started appearing in the restaurant, in addition to the image of Xian'er, but by December packages and decorations were using only the bird icon. At the same time, the restaurant changed its name to Gu'er Family (Gu'er Jia 故二家). In mid-March 2019 the exterior and interior were refurbished, with a change of color, and the image of Xian'er disappeared completely. On March 15, 2019, a post on the WeChat account of the restaurant explained that a name is just a name and asked customers to focus on the new goods and menu instead; yet, some users' comments below the post complained about the disappearance of Xian'er. ${ }^{42}$ From these expressions of disappointment we may conclude that Xuecheng's downfall in late 2018 does not mean that Xian'er is no longer popular.

Longquan Monastery organized a photo exhibition on the character of Xian'er at the Animation Center as part of the festivities celebrating Chinese National Day (guoqingjie 国庆节) in 2017.43 Xian'er also participated in art events outside the monastery, appearing at the Guangzhou Cartoon and Animation Festival (2015); the Xinhua 1949 Creative Carnival, organized by the Xinhua 1949 Cultural and Financial Innovation Center (2016); the fifth Chinese Independent Animation Film Forum, held at the 798 Art District (2016); and the Intelligent Robot Show (2017). These were all ways to bring Xian'er, and Buddhism, outside the monastery and outside the usual Buddhist environment, occasions that, in turn, enabled the Buddhist community to engage with a nonreligious sphere.

When asked to introduce the figure of Xian'er, Xuecheng argued often that “We are all Xian'er” (women doushi Xian'er 我们都是贤二) and explained how the character Xian'er represents each of us, monastic or lay, because we all have a Xian'er in our heart (women meiyige ren xinli dou you yige Xian'er 我们每一 个人心里有一个贤二). Xuecheng added that Xian'er speaks with the voice

42 “The Restaurant Gu'er Family Changed its Look, Come Back and Have a Look!” 故二家餐 厅换新颜, 常回家看看哦 , March 15, 2019, https://mp.weixin.qq.com/s/kzyDMJgl UAPJQcyVnyjJfA; “After the Restaurant Gu'er Family Changed its Look, Little Birds Were so Moved that They Almost Cried” 故二家门椐换妆后, 菜鸟们感动到快流泪, why?, https://mp.weixin.qq.com/s/mzQFvxrOıDuQi2Kv5JypDQ (both accessed July 1, 2019).

43 See the news item posted on October 1, 2017: "Xian'er Explores the World: Special Photographic Exhibition - Opening Ceremony” 贤二看世界摄影展特刊 - 开幕, https:// mp.weixin.qq.com/s/bR5KoyAXQhq-fcKoCJ8qLA (accessed on July 1, 2019). 
of a child and does not age, while we all age; it is like the young practitioner who is inside each of us, with its attachments and imperfections but still determination to learn the way. The character $e r$ in his Dharma name refers to the Dharma gate of non-duality (bu'erfamen 不二法门); Xian'er also resides at the Temple of Non-Duality. From a different angle, experiencing the non-duality of relative and absolute truths is a difficult task and done at a high stage of practice. Xian'er, who has not reached that level yet, cannot perceive duality as non-duality. This is why its Dharma name has duality in it (Xian'er, with $\mathrm{er}$ 二 meaning "two"), and it is not named Xian'yi (with $y i$ - meaning "one/unity," hence the experience of relative and absolute truths not as separate realities). Xian'er is often called lüshi 律师 (lawyer) to emphasize the importance of the Vinaya in monastic practice. Discipline and precepts constitute the basis of Buddhist practice, something to learn at the beginning of the Way, and Xian'er is thus seen as still learning at the beginning of the way.

When I interviewed clerics at the Longquan Monastery, I was told that technology is just an expedient (fangbian 方便; Skt. upāya) and that Xian'er has to be evaluated as a skillfully engineered method to attract more people to the monastery, and to the Dharma teachings via visits to the monastery. At the same time, Xian'er mirrors any monk at the monastery; hence, as you feel interest in Xian'er you should also feel interest in the monastery and the resident sangha. ${ }^{44}$ So far, the plan seems to have been quite successful, as visits to the monastery have increased, according to the Longquan community. Furthermore, a report made at Longquan states that from April 2016 to January 2017, an average of thirteen articles about Xian'er were published on social media every day, and 770,000 users have responded to those articles online and so proved to be aware of the existence of the robot-monk.

We can conclude that in a very few years Xian'er has become a brand, inclusive of comics, gadgets, animated cartoons, a robot, digital media, and even a restaurant. As Longquan monastics told me, Xian'er is better known than Xuecheng outside of China. ${ }^{45}$ A survey of the comments posted on WeChat confirms that Xian'er lives in the minds of WeChat users as a reality independent from the monastery that created it. The fact that Xuecheng's name does not appear in the comics might also have prevented Xian'er's fans from linking the two figures. When the name of Xian'er disappeared from the vegetarian restaurant a few months ago, the disappointed customers called for a return of Xian'er, with no mention of Xuecheng or Longquan.

44 Interviews in Beijing in September-October 2017, and June 2019.

45 Interviews in Beijing in September-October 2017. 
On the other hand, Xian'er should also be understood within the context that gave it birth; the identity of Xian'er then partakes of Longquan's identity, or, in other words, the "Xian'er brand" has been defined, explicitly, as one of the key features of the larger "Longquan model." For instance, in his Weibo account, Xuecheng celebrated the high number of netizens-100,00o per daywho were chatting with the robot-monk Xian'er as an excellent achievement for the Longquan Buddhist community. During Xuecheng's abbotship, Longquan became a symbol of modernization and innovation, as manifested by the translation of Xuecheng's texts into several languages, the opening of branch temples abroad, and the activities of its successful charity (see McCarthy 2019); the adoption of several media platforms and advanced technology have been important chapters in Longquan's long-term project and have partaken of the distinctive identity of the monastery.

\subsection{Xian'er and Robotics in World Religions: from BlessU2 to In-myung}

Xian'er is not the only automaton in the history of Buddhism, and certainly robotics have been adopted by other religious groups as well. For instance, we have the cases of BlessU2, the Protestant robot-priest that gives blessings in five languages, with either a male or a female voice, created to mark the fivehundredth anniversary of the Reformation (Sherwood 2017), and robot-assisted performances of a Hindu puja in both the public and private spheres (Bhattacharya 2017) ${ }^{46}$

Public opinion about the use of robots in religion has not been unanimous, and the views of religious personnel are similarly divided. Religious leaders, in fact, have expressed concern and consternation about the notion of adopting robotics to replace humans in liturgies, using both doctrinal and ethical perspectives. For instance, although the Roman Catholic Church has expressed approval of the use of technology to spread the Christian message and improve communication with believers, some Catholics have strongly argued that robots cannot replace human priests (Francis-Smith 2017). In Judaism, the adoption of technology and artificial intelligence has generated questions and controversies from the creation of kosher cell phones (Rashi 2013) to the various interpretations of the story of the humanoid golem; ${ }^{47}$ in the case of

46 General academic sources on religion and technology that also address artificial intelligence include Vallverdú 2011, Stolow 2013, Lim 2009, Geraci 2006, Han 2016, and Sturgill 2019. In addition, online news sites have also posted reports on the presence and use of artificial intelligence in religion; see, for instance, Samuel 2019. 
robots specifically, the question rests on whether the robot may possess the consciousness of discernment (Rosenfield 1966). The use of technology is not forbidden in Islam, nor is the creation of robots; however, creating anything that resembles Allah's creation is considered a haraam (sinful act), as various hadiths report. ${ }^{48}$ In Hinduism, the adoption of media and technology in the religious sphere has fostered a process of democratization in ritual participation, which undermines traditional restrictions imposed by the caste system (see Scheifinger 2015 ${ }^{49}$ ); there have also been critical responses to the use of robots (Bhattacharya 2017).

Other cases of Buddhist robots are found in the rest of East Asia. In Japan, the robot-priest Pepper has been officiating funerals and other liturgies for years; however, Xian'er is a single robot created specifically for a Buddhist environment, while Pepper is a semi-humanoid robot invented by the SoftBank Group Corporation in 2014, sold on the mass market since 2015, and adopted as a robot-priest by the Japanese Buddhist community since 2017. ${ }^{50}$ Like Xian'er, Pepper has been used by Buddhists to meet the demands of contemporary society, but, unlike Xian'er, Pepper serves the community specifically for death and funerary rituals, and in fact was unveiled at the largest funerary expo in Japan (2015). In March 2019, a Buddhist temple, the Kodai-ji (Gaotai si 高台寺) in Kyoto, inaugurated Mindar, an android representing the Bodhisattva of Compassion (Jp: Kannon; Ch: Guanyin 观音) that recites and explains the Heart Sutra to those who come to the temple (Siripala 2019). This occurred just a few years after a video that featured the famous vocaloid (voice synthesizer) software Hatsune Miku 初音ミク reciting the Heart Sutra, accompanied by a cartoon of the eminent master Kukai playing the wooden fish, went viral; Hatsune Miku was the first "high-tech device" to popularize this Buddhist text among non-Buddhists, especially the youth. Mindar shares two characteristics with Xian'er: first, like Xuecheng and the other monks at the Longquan Monastery, Mindar's creators aim to attract new believers to Buddhism (and specifically to the Kodai-ji), particularly those of a younger generation; second, like Xian'er, Mindar is the result of a collaboration between a Buddhist community

golem; they appeared in sacred scriptures before becoming the protagonists of medieval folk stories. See Idel 1990.

48 For more about Islam's position and ethical concerns on the adoption of artificial intelligence, see Ziaee 2012, and Sturgill 2019.

49 Scheifinger's book chapter explores how the Internet has contributed to the standardization and homogenization of Hindu worship and the disembedding of Hindu images from traditional sacred sites, and how online Hinduism is democratizing religious practice and enabling diaspora Hindu communities to keep in touch with their religious roots.

For more about Buddhist Pepper, see Rambelli 2018. 
and experts in advanced technology and artificial intelligence. Unlike Xian'er, Mindar is not imagined to be an average Buddhist monastic practitioner: it does not interact with others like Xian'er does, and has even been revered by the temple priests, who have prayed and prostrated themselves in front of it as they would do with an icon of any other Bodhisattva. No one makes prostrations or bows in front of the robot Xian'er. Korean filmmakers have gone beyond this with the story Chunsangui Pijomul (The Heavenly Creature), one of three episodes in the 2012 science-fiction anthology Inryu Myeongmang Bogoseo (usually known in English as Doomsday Book, and in Chinese as Renlei miewang baogaoshu 人类灭亡报告书), directed by Kim Jee-woon and Yim Pil-sung. The three stories from Doomsday Book concern a possible human self-destruction in a time when modern high-tech is predominant; the movie questions the usefulness and danger of technology, and the possibility of automata taking over humankind. In The Heavenly Creature, In-myung is a robot that lives in a Buddhist monastery, it becomes a Buddhist, and somehow also achieves independence from the humans who created it and escapes their control; the robot eventually reaches Enlightenment and enters Nirvana. The robot-Buddha generates various reactions among humans: the Buddhist community shows veneration toward the enlightened robot, while the corporation that invented the robot decides to exterminate it out of fear; the robot-creation was not responding to the commands of its human creators any longer, and it had achieved something (i.e., Buddhist enlightenment) that they did not. This was in line with the underlying narrative of the overall movie.

In a recent article on Dharma devices in Japan, Fabio Rambelli (2018) contextualized the Japanese Buddhist adoption of robots within the history of Japan and in relation to legends about the presence of robots in ancient Japan; he showed that there has been continuity in the attention to, and employment of, robotics within and outside of the religious sphere. In his analysis, Rambelli also reported the Japanese scholar Mori Masahiro's (1999) view on the ontological identity of human beings and machines, and his conviction that Buddha-nature is present in the entire universe, including in robots. Furthermore, Rambelli recalled Umberto Eco's (2003) classification of objects that extend the natural capacities of human beings, underlining the difference between machines that are operated by human power (and as an extension/enhancement of that same human power) and machines that become independent from human power. Eco emphasized that we are gradually moving to a world of machines that are more and more independent from humans, in a way that dehumanizes the relations between humans and those machines; ${ }^{51}$ I also agree 
with Rambelli that, from a different angle, we cannot but notice that machines have been humanized in shape and function. Regarding the humanization of machine devices, Min-sun Kim and Eun-joo Kim (2013:310) argued that "[c]reating human-like android robots raises an issue of identity and ethics because they look and act like us"; some negative reactions to In-myung and Buddhist Pepper seem to validate this idea. Xian'er, however, does not officiate ceremonies: its story is based on the narrative of the homonymous comic figure, and the fact that it "look[s] and act[s] like us" is seen by both its creators and its fans as a factor that helps it to attract people to the temple, rather than as a source of fear, as in the case of In-myung's "human-like" achievement of enlightenment.

As we have seen earlier, the creation and function of Xian'er can be explained in Buddhist terms, starting with the concept of skillful means. However, can a robot serve as a fully ordained monk? According to Mori (1999), everything potentially has Buddha-nature; hence, in Buddhist terms, there cannot be a difference between humans and robots. In Japan, as noted above, the robot-priest Pepper has been officiating funerals and other liturgies for some time, and those rituals are not conceived by monastics or most of the laity as less valid than those conducted by human monks; Mindar is also respected and honored by the monastic community of the host temple. Mori's view reflects also the Japanese Shinto belief in the kami, as reported by Robert Geraci (2006) in his study of "spiritual robots." ${ }^{2}$ And in South Korea, the robot In-myung does not just serve in the temple-it even becomes a Buddha, lectures human beings, displays "superhuman abilities" (shentong 神通), and eventually enters Nirvana. Nevertheless, when asked whether robots (including robot-monks) could replace or become even better than humans, Chinese monastics from Longquan replied negatively, as robots do not have consciousness (yet). The different views expressed by Mori and Chinese monks may also reflect the different histories (and stories) of automata in Japan (Rambelli 2018) and China. In fact, Xian'er may not be a new entry in religion and Buddhism, but it is certainly a new phenomenon in the history of Chinese religion. Overall, advanced technology and artificial intelligence started to become popular in China later than in Japan; therefore, we may not find stories and legends about robots in Chinese history or mythology, and as a result China

52 Quoting Geraci (2006:230): "The Japanese enjoy the presence of robots in their midst thanks in part to the Shinto perspective that the world is full of kami, sacred entities. The sacred nature of the world includes robots, whose own sanctity makes them natural partners to human beings." 
lacks the long-term milieu that Japan offers for contextualizing Dharma machines.

At the same time, despite its short history, robotics in China has developed quickly, not only within the religious domain but also in other sectors like various industries and medical care or even literature. Moreover, when it comes to traditional Chinese culture, Xian'er is not the only robot to have been created. Confucian thinkers, for instance, have also been represented as androids, as in the case of Wang Yangming 王阳明 (1472-1529). The latter was not a popular Confucian thinker in Communist China, given his philosophy of autonomy; however, official opinion on him started to change at the beginning of the twenty-first century, probably as an effect of the overall revival of Confucianism, the revaluation of the icon of Confucius (see, for instance, Puppin 2016), and the revaluation of Confucian ideals toward a Confucianized configuration of Chinese politics. In 2014, one year after opening, the Guiyang Confucian Academy made Wang Yangming its absolute idol; a robot-calligrapher replica of Wang Yangming is now located in the Wang Yangming-themed park in Guiyang. During an interview, Ms. Zhou Ying, the manager of the robot, stated that the creation of the robot-calligrapher aimed "to get people interested in these old ideas" (Johnson 2017), which is also what the Longquan community argued with respect to the function of Xian'er.

\section{3 "Spiritual Robots": between Embodiment and Misembodiment}

The emerging scholarship on artificial intelligence may offer further perspectives on the study of Xian'er and the creation of Buddhist robotics in China. In his article on "spiritual robots," Geraci (2006) argued that robots might be a good alternative to humans in religious and spiritual matters, as they transcend human life and are purified of any humanness; Geraci defined this process as "misembodiment." The case of the robot-Buddha In-myung can certainly be described in these terms; the same argument, and the concept of "misembodiment," may not always be suitable for our Xian'er, however. The human features of the robot are often highlighted by the Longquan community: Xian'er is naughty, loves ice cream, tends to be lazy, and may lecture about the Dharma but also speaks like a young boy. At the same time, the comics where cartoon-protagonist Xian'er and robot-monk Xian'er interact suggest a distinction between a more human cartoon and a robot that has been purified of any humanness.

Min-sun Kim and Eun-joo Kim (2013) considered human-shaped robots as "the cultural other" and compiled a sixfold classification of humanoid robots as "the cultural other," namely (1) robots as frightening others; (2) robots as subhuman others; (3) robots as human substitutes; (4) robots as sentient 
others; (5) robots as the divine other; and (6) robots as the coevolutionary path to immortality. Kim and Kim focused on humanoid robots, a category that they added to Sebastian Thrun's (2004) classification of (1) industrial robots; (2) professional service robots; and (3) personal service robots. Some of these six categories of humanoid robots are applicable to the case of Xian'er. If we consider its interaction with believers (or fans) on WeChat, Xian'er may be seen as a robot in the function of a "human substitute." Robot Xian'er can also be apprehended as a "sentient/living other," in the way that (some varieties of) Buddhism and (some) Buddhists perceive non-duality and the presence of Buddha-nature within anything in the universe; the last point draws an important divide between the Catholic and Buddhist readings of the ontology of robots.

\subsection{From the Perspective of Posthumanism}

Posthumanistic discourses over the late twentieth century, and the reconsideration of "the human" and its alternatives, may also intersect with the creation and functions of Xian'er and contribute to how we interpret it in relation to its human followers.

In her important works on posthumanism, Katherine N. Hayles (1999, 2003, 2004, 2010) stressed that a key feature of the posthuman is the decentering of the human subject so as to let something else emerge. At the same time, Hayles (2003:137) argued that the human does persist in the posthuman; in fact, it is not possible to understand the posthuman fully without taking the human into account. There is neither a diachronic nor a synchronic division between nature and technology (Hayles 2003:134); Hayles borrowed the notion of "seriation" from archaeological anthropology to frame this form of overlapping and replication.

The interconnection (and interdependence) between human and posthuman, nature and technology, and the concept of seriation could also be used to describe the intersection between offline and online that has been so much debated in the field of religion and media, and it may also capture the complexity of the Xian'er phenomenon. Xian'er is a robot, but it was created to mirror an average monastic in his early stage of practice, and, like many monastics, Xian'er also has a WeChat account to interact with other (human) Buddhist believers. Indeed, the robot could not have existed or become relevant if not for this close interdependence with the homonymous comic figure and the human sangha, which are the main reference points in the construction of its existence. This synchronic overlapping and replication (or seriation) may make Xian'er an example of a posthuman reality where the human is still present and necessary. 
It is evident that Buddhism and the media have had a long history of interaction in mainland China, a history whose most recent stages are rooted in historical and political changes in the country, cross-strait relations with Taiwan, and the merging of religious services and social development. The Chinese story is thus complex, and differing voices have emerged arguing for both the usefulness and disadvantages of Buddhist adoption of the media.

Xian'er may be labeled a "celebrity monk," given its popularity at the monastery, abroad, and online, even after Xuecheng's downfall in late 2018; its ability to entertain with its clumsiness and funny stories while it educates readers and listeners with Dharma speeches reminds us of Singhal and Rogers's concept of edutainment. In addition, Xian'er is a mirror of every human monk, which places it in the category of robots as "human substitutes," to return to Kim and Kim's (2013) understanding of robots as "the cultural other." And it is also a "posthuman reality where the human is still present," to read it according to Hayles's (2003) work. In fact, Xian'er has become a multifaceted enterprise: it is not just a robot, and the robot would not be what it is without the underlying narrative explicated in the comics, as reflected in the life and practice of the surrounding sangha at Longquan and in its relation with human followers.

Xian'er reflects and embeds-and in its cartoons and animation also performs - Dharma teachings, and thus has become an exemplary Buddhist product in this new media and high-tech age. The Xian'er phenomenon is a feature of the Longquan model, and also one of the many elements of the religious mediascape and the development of artificial intelligence in contemporary China. It is a way for Buddhists to keep Buddhism up to date, and also a trope enabling them to introduce and affirm Buddhism in nonreligious and innovative environments.

\section{Acknowledgements}

I would like to thank monastics and volunteers at the Longquan Monastery (Beijing) for their kindness in answering all my questions and discussing the "Xian'er phenomenon" with me. I am especially grateful to the Longquan Animation Center for their assistance, and the opportunities I had to interview the robot Xian'er. Drafts of this article were presented at National Cheng Chi University (April 2018) and the University of Perugia (May 2018); I am indebted to all the comments and suggestions I have received on those occasions from colleagues. Finally, I would like to thank the anonymous reviewers for their valuable notes. 


\section{References}

Bartholomeusz, Tessa J. 2002. In Defense of the Dharma: Just-War Ideology in Buddhist Sri Lanka. London: Routledge.

Bhattacharya, Ananya. 2017. "The Robots Are Coming for One of Hinduism's Holiest Ceremonies." Quartz India. September 4. https://qz.com/india/1066718/the-robots -are-coming-for-one-of-hinduisms-holiest-ceremonies / (accessed July 4, 2019).

Chia, Jack Meng-Tat. 2015. "Toward a Modern Buddhist Hagiography: Telling the Life of Hsing Yun in Popular Media." Asian Ethnology 74 (1): 141-165.

Cho, Francisca. 2003. "The Art of Presence: Buddhism and Korean Films." In Representing Religion in World Cinema: Filmmaking, Mythmaking, Culture Making, edited by S. Brent Plate, pp. 107-120. London: Palgrave Macmillan.

Eco, Umberto. 1997. Kant e l'Ornitorinco. Milan: Bompiani.

Eco, Umberto. 2003. "Osservazioni sul Design del Futuro Prossimo." DDD Colore. Rivista Trimestrale Disegno e Design Digitale 2 (6): 1-4.

Francis-Smith, Alexander. 2017. "The Protestant 'Robot Priest' Shows Us One Thingthe Priesthood Cannot Be Replaced." Catholic Herald. June 5. https://catholicherald .co.uk/commentandblogs/2017/06/05/the-protestant-robot-priest-shows-us-one -thing-the-priesthood-cannot-be-replaced/ (accessed July 4, 2019).

Gandhi, Lakshmi. 2017. "Explore the Bardos in Mandagon, a Video Game Inspired by Tibetan Buddhism." Tricycle. https://tricycle.org/trikedaily/explore-the-bardos-inman dagon-a-video-game-inspired-by-tibetan-buddhism/ (accessed December 10, 2018).

Gao, Fei 高飞. 2013. "Fojiao wenhua yu zhongguo dianying" 佛教文化与中国电影. (Buddhist Culture and Chinese Films). Beijing: Zhongguo chuanmei daxue chubanshe 北京: 中国传媒大学出版社.

Geraci, Robert M. 2006. "Spiritual Robots: Religion and Our Scientific View of the Natural World." Theology and Science 4 (3): 229-246.

Han, Sam. 2016. Technologies of Religion: Spheres of the Sacred in a Post-secular Modernity. London: Routledge.

Hayles, Katherine. 1999. How We Became Posthuman: Virtual Bodies in Cybernetics, Literature, and Informatics. Chicago: University of Chicago Press.

Hayles, Katherine. 2003. "The Human in the Posthuman." Cultural Critique 53: 134-137. Hayles, Katherine. 2004. "Refiguring the Posthuman." Comparative Literature Studies $41(3): 311-316$.

Hayles, Katherine. 2010. "How We Became Posthuman Ten Years On: An Interview with N. Katharine Hayles." Paragraph 33 (3): 318-330.

Helland, Christopher. 2014. "Virtual Tibet: From Media Spectacle to Co-Located Sacred Space." In Buddhism, the Internet, and Digital Media, edited by Gregory Price Grieve and Daniel Veidlinger, pp. 155-172. London: Routledge. 
Huang, Weishan. 2016. "WeChat Together about the Buddha: The Construction of Sacred Space and Religious Community in Shanghai through Social Media." In Religion and Media in China: Insights and Case Studies from the Mainland, Taiwan and Hong Kong, edited by Stefania Travagnin, pp. 110-128. London: Routledge.

Hui, Yuk. 2016. The Question concerning Technology in China: An Essay in Cosmotechnics. Falmouth: Urbanomics.

Huikong 慧空. 2012. Stories of Ven. Master Xuecheng (Xuecheng daheshang ceji 学诚大 和尚侧记). Beijing: Zhongguo Wuzi chubanshe 北京：中国物资出版社.

Huikong 慧空. 2016. Stories of Ven. Master Xuecheng (Xuecheng daheshang ceji 学诚大 和尚侧记). 2nd ed. Beijing: China Forum Press.

Idel, Moshe. 1990. Golem: Jewish Magical and Mystical Traditions on the Artificial Anthropoid. Albany: sunY Press.

James, David E. 2002. "Im Kwon-taek: Korean National Cinema and Buddhism." In Im Kwon-taek: The Making of a Korean National Cinema, edited by David E. James and Kyung-hyun Kim, pp. 47-83. Detroit: Wayne State University Press.

Ji, Zhe 波喆, Tian Shuijing 田水晶, and Wang Qiyuan 王启元, eds. 2016.二十世纪中 国佛教的两次复兴 [The Two Revivals in Twentieth-century Chinese Buddhism]. Shanghai: Fudan daxue chubanshe.

Jinmyong, Sunim. 2006. "Buddhist Nuns on Radio and Television: Disseminating Buddhism through the Mass Media in Korea." In Out of the Shadows: Socially Engaged Buddhist Women, edited by Karma Lekshe Tsomo, pp. 339-344. Delhi: Sri Satguru Publications.

Johnson, Ian. 2017. "Forget Marx and Mao. Chinese City Honors Once-Banned Confucian." New York Times. October 18. https://www.nytimes.com/2017/10/18/world/asia/ china-guiyang-wang-yangming-confucian.html (accessed December 15, 2018).

Johnson, Ian. 2018. "\#MeToo in the Monastery: A Chinese Abbot's Fall Stirs Questions on Buddhism's Path." New York Times. September 15. https://www .nytimes.com/2018/og/15/world/asia/metoo-china-monastery.html (accessed July $15,2019)$.

Kim, Min-sun, and Kim, Eun-Joo. 2013. "Humanoid Robots as 'The Cultural Other': Are We Able to Love Our Creations?” AI \& Society 28 (3):309-318.

Lengen, Samuel. 2016. "Beyond the Conceptual Framework of Oppression and Resistance: Creativity, Religion and the Internet in China." In Religion and Media in China: Insights and Case Studies from the Mainland, Taiwan and Hong Kong, edited by Stefania Travagnin, pp. 19-34. London: Routledge.

Lim, Francis K. G. 2009. "Charismatic Technology." In Mediating Piety: Technology and Religion in Contemporary Asia, edited by F. K. G. Lim, pp. 1-24. Leiden: Brill.

McCarthy, Susan. 2019. "Spiritual Technologies and the Politics of Buddhist Charity." In Buddhism after Mao: Negotiations, Continuities, and Reinventions, edited by Zhe Ji, Gareth Fisher, and André Laliberté. Honolulu: University of Hawai'i Press. 
McGuire, Beverley. 2016. "Buddhist Blogs in Mainland China and Taiwan: Discussing Buddhist Approaches to Technology." In Religion and Media in China: Insights and Case Studies from the Mainland, Taiwan and Hong Kong, edited by Stefania Travagnin, pp. 151-166. London: Routledge.

McGuire, Beverley. 2019. "Digital Media and Global Buddhism." In Religion Online: How Digital Technology Is Changing the Way We Worship and Pray, vol. 2, edited by August E. Grant, Amanda F. C. Sturgill, Chiung Hwang Chen, and Daniel A. Stout, pp. 232-249. Santa Barbara: ABC-CLIO.

Mengin, F. ed. 2004. Cyber China: Reshaping National Identities in the Age of Information. New York: Palgrave MacMillan.

Mori, Masahiro. 1999. The Buddha in the Robot: A Robot Engineer's Thoughts on Science and Religion. Tokyo: Kosei.

Pacey, Scott. 2016. "Eminence and Edutainment: Xingyun and Daoxin as Television Celebrities." In Religion and Media in China: Insights and Case Studies from the Mainland, Taiwan and Hong Kong, edited by Stefania Travagnin, pp. 225-240. London: Routledge.

Pickard, Victor, and Yang Guobin, eds. 2017. Media Activism in the Digital Age. London: Routledge.

Puppin, Giovanna. 2016. "The Master Said, the Master Sold? Uses and Misuses of the Confucius Icon in Chinese Commercial Advertising." In Religion and Media in China: Insights and Case Studies from the Mainland, Taiwan and Hong Kong, edited by Stefania Travagnin, pp. 203-224. London: Routledge.

Rambelli, Fabio. 2018. "Dharma Devices, Non-Hermeneutical Libraries, and RobotMonks: Prayer Machines in Japanese Buddhism." Journal of Asian Humanities at Kyushu University 3: 1-19.

Rashi, Tsuriel. 2013. "The Kosher Cell Phone in Ultra-Orthodox Society: A Technological Ghetto within the Global Village." In Digital Religion: Understanding Religious Practice in New Media Worlds, edited by Heidi Campbell, pp. 173-181. London: Routledge.

Rosenfield, Azriel. 1966. "Religion and the Robot." Tradition: A Journal of Orthodox Jewish Thought 8 (3): $15^{-26 .}$

Samuel, Sigal. 2019. "Robot Priests Can Bless You, Advise You, and Even Perform Your Funeral: AI Religion Is Upon Us. Welcome to The Future." Vox's Future Perfect. January 13. https://www.vox.com/future-perfect/2019/9/9/20851753/ai-religion-robot-priest -mindar-buddhism-christianity (accessed October 30, 2019).

Scheifinger, Heinz. 2015. "New Technology and Change in the Hindu Tradition: The Internet in Historical Perspective.” In Asian Religions, Technology and Science, edited by István Keul, pp. 153-168. London: Routledge.

Schicketanz, Eric. 2017. "Narratives of Buddhist Decline and the Concept of the Sect (zong) in Modern Chinese Buddhist Thought." Studies in Chinese Religions 3 (3): 281-300. 
Sherwood, Harriet. 2017. "Robot Priest Unveiled in Germany to Mark 500 Years since Reformation." Guardian, May 30. https://www.theguardian.com/technology/2017/ may/3o/robot-priest-blessu-2-germany-reformation-exhibition (accessed July 3, 2019).

Singhal, Arvind, and Everett Rogers. 1999. LEA's Communication Series. EntertainmentEducation: A Communication Strategy for Social Change. Mahwah, NJ: Lawrence Erlbaum.

Siripala, Thisanka. 2019. “An Ancient Japanese Shrine Debuts a Buddhist Robot." Diplomat. March 5. https://thediplomat.com/2019/o3/an-ancient-japanese-shrine-de buts-a-buddhist-robot/ (accessed July 4, 2019).

Stolow, Jeremy, ed. 2013. Deus in Machina: Religion, Technology and the Things in Between. New York: Fordham University Press.

Sturgill, Amanda F. C. 2019. "Artificial Intelligence: Its Future Uses in Religious Compassion." In Religion Online: How Digital Technology is Changing the Way We Worship and Pray, vol. 1, edited by August E. Grant, Amanda F. C. Sturgill, Chiung Hwang Chen, and Daniel A. Stout, pp. 57-66. Santa Barbara: ABC-CLIo.

Tarocco, Francesca. 2007. The Cultural Practices of Modern Chinese Buddhism: Attuning the Dharma. London: Routledge.

Tarocco, Francesca. 2017. "Technologies of Salvation: (Re)locating Chinese Buddhism in the Digital Age." Journal of Global Buddhism 18: 155-175.

Tarocco, Francesca. 2019. "Charismatic Communications: The Intimate Publics of Chinese Buddhism." In Concepts and Methods for the Study of Chinese Religions III: Key Concepts in Practice, edited by Paul R. Katz and Stefania Travagnin, pp. 113-132. Boston: De Gruyter.

Thrun, Sebastian. 2004. "Toward a Framework for Human-Robot Interaction." HumanComputer Interaction 19 (1): 9-24.

Travagnin, Stefania, ed. 2016a. Religion and Media in China: Insights and Case Studies from the Mainland, Taiwan and Hong Kong. London: Routledge.

Travagnin, Stefania. 2016b. "Charting Religion and Media in Taiwan: Media Expressions of Faith as (Pluri)Identity Markers in the Democratization Era." In Religion and Media in China: Insights and Case Studies from the Mainland, Taiwan and Hong Kong, edited by Stefania Travagnin, pp. 53-68. London: Routledge.

Travagnin, Stefania. 2016c. "Dharma in Motion Pictures: Buddhist Cartoons and Documentaries in Contemporary Taiwan." In Religion and Media in China: Insights and Case Studies from the Mainland, Taiwan and Hong Kong, edited by Stefania Travagnin, pp. 225-240. London: Routledge.

Travagnin, Stefania. 2019. "Cyber-activities and 'Civilized' Worship: Assessing Contexts and Modalities of Online Ritual Practices." In Buddhism after Mao, edited by Ji Zhe, Gareth Fisher, and André Laliberté, pp. 290-311. Honolulu: University of Hawai'i Press. 
Travagnin, Stefania, and André Laliberté. 2019. "Epistemic Communities of Buddhist Scholarship in Modern China: Narratives and Paradigms." In Concepts and Methods for the Study of Chinese Religions I: History of the Field and Disciplinary Approaches, edited by Stefania Travagnin and André Laliberté, pp. 115-138. Boston: De Gruyter.

Vallverdú, Jordi. 2011. "The Eastern Construction of the Artificial Mind." Enrahonar: Quaderns de Filosofia 47: 171-185.

Wilkinson, James. 2017. "Ready Prayer One! New Video Game Lets Players Beat Up Buddha, Zeus, Moses - and Even Jesus, Who Fights Back with Chunks of the Cross Still Nailed to His Fists." Daily Mail Online. https://www.dailymail.co.uk/news/ article-4858284/New-video-game-lets-players-beat-Buddha-Zeus-JESUS.html (accessed December 6, 2018).

Xuecheng 学诚. 2012. “从媒体传播看东西方文明的差异 ['Explaining the Differences between Eastern and Western Civilization from the Perspective of Media and Communication].” 法音 [The Voice of Dharma] 2012 (4): 25.

Xuecheng 学诚, Xianfu 贤帆, and Xianshu 贤书. 2014. 烦恼都是自找的 [I am the Creator of My Own Troubles]. Beijing: Zhongguo youyi chubanshe.

Xuecheng 学诚, Xianfu 贤帆, and Xianshu 贤书. 2015a. 放下是舍更是得 [It is Even Better When You Let Go]. Beijing: Huawen chubanshe.

Xuecheng 学诚, Xianfu 贤帆, and Xianshu 贤书.2015b. 快乐就这么简单 [Happiness Can Be So Simple]. Beijing: Huawen chubanshe.

Zhang, Fan. 2015. "Remaking Ancient Virtues for the Virtual World: A Case Study of the 'Voice of Longquan." International Journal of Interactive Communication Systems and Technologies 5 (1): 41-55.

Ziaee, Ali Akbar 2012. "A Philosophical Approach to Artificial Intelligence and Islamic Values." IIUM Engineering Journal 12 (6): 73-78.

Zhang, Yuehe 張月荷. 2017. 北京龍泉寺 : 移動互聯網時代的中國漢傳佛教 [The Longquan Monastery in Beijing: Chinese Han Buddhism in the Era of Mobile Internet]. MA thesis, National Chengchi University, Taipei. 